\title{
Sorpsi Isotermi dan Daya Patah Emping Jagung Pulut
}

\section{Isothermy Sorpsion and Broken Power of Pulut Corn Chip}

\author{
Kaslam $^{1 *}$, Salengke ${ }^{2)}$, dan Helmi A. Koto ${ }^{2)}$ \\ $\left.{ }^{1 *}\right)$ Universitas Islam Negeri Alauddin Makassar \\ 2) Program Studi Keteknikan Pertanian, Fakultas Pertanian, Universitas Hasanuddin, Makassar \\ $\left.{ }^{*}\right)$ email korespondensi: etos.kaslam@uin-alauddin.ac.id
}

\begin{abstract}
Corn production in Indonesia is quite high, namely 18,364,430 tons with a total harvest area of $4,131,676$ ha and productivity of $41.18 \%$ (BPS, 2010). One type of corn that is potential and widely developed is pulut corn. This type of corn is very suitable in making corn chips because it has a high amylopectin content $(>80 \%)$. Pulut corn chips are produced by many small to medium scale industries as snack food products. The problem that then occurs is the handling of post-production, corn chips have a high ability of water absorption so that when fried, it does not bloom perfectly so that it is less tasty to consume. The aim of this research is to test the sorption isotherm equations of corn chips that provide the approximate balance of water content that is closest to the measured equilibrium water content. By using temperatures of $25^{\circ} \mathrm{C}, 30^{\circ} \mathrm{C}$ and $35^{\circ} \mathrm{C}$ with a combination of $40 \%, 60 \%$ and $80 \% \mathrm{RH}$, this study shows that the Henderson equation provides an estimate of the behavior of isotermic soring sorut corn chips that is at a temperature condition of $30^{\circ} \mathrm{C}$ closer to the results experiment and also at a temperature of $35^{\circ} \mathrm{C}$. Whereas the Chung \& Pfost equation best describes the behavior of isothermic absorption at $25^{\circ} \mathrm{C}$. In addition, this study also aims to determine the fragility (fracture) of pulut corn chips in various storage conditions. Research shows that the higher the RH environment, the higher the fracture value.
\end{abstract}

Keywords: Balance water content, Isothermic sorption, Corn pulping

\begin{abstract}
ABSTRAK
Produksi jagung di Indonesia cukup tinggi, yaitu 18.364.430 ton dengan total luas panen 4.131.676 ha dan produktivitas sebesar 41,18\% (BPS, 2010). Salah satu jenis jagung yang potensial dan banyak dikembangkan adalah jagung pulut. Jenis jagung ini sangat cocok dalam pembuatan emping jagung karena memiliki kandungan amilopektin tinggi (>80\%). Emping jagung pulut banyak diproduksi oleh industri skala kecil hingga menengah sebagai produk makanan ringan. Permasalahan yang kemudian terjadi adalah penanganan pasca produksi, emping jagung memiliki kemampuan penyerapan air yang tinggi sehingga saat digoreng, tidak mekar dengan sempurna sehingga kurang enak dikonsumsi. Penelitian ini bertujuan untuk menguji persamaan sorpsi isotermi emping jagung yang memberikan perkiraan kadar air keseimbangan yang paling mendekati kadar air keseimbangan terukur. Dengan menggunakan suhu $25^{\circ} \mathrm{C}, 30^{\circ} \mathrm{C}$ dan $35^{\circ} \mathrm{C}$ dengan kombinasi $\mathrm{RH}$ 40\%, 60\% dan 80\%, penelitian ini menunjukkan bahwa Persamaan Henderson memberikan perkiraan perilaku sorpsi isotermi emping jagung pulut yaitu pada kondisi suhu $30^{\circ} \mathrm{C}$ lebih mendekati hasil percobaan dan juga pada suhu $35^{\circ} \mathrm{C}$. Sedangkan Persamaan Chung \& Pfost paling baik menggambarkan perilaku sorpsi isotermi pada suhu $25^{\circ} \mathrm{C}$. Selain itu, Penelitian ini juga bertujuan untuk mengetahui kerapuhan (daya patah) emping jagung pulut pada berbagai beberapa kondisi penyimpanan. Penelitian menunjukkan bahwa semakin tinggi RH lingkungan maka Nilai daya patah semakin tinggi pula.
\end{abstract}

Kata Kunci: Kadar air keseimbangan, Sorpsi isotermi, Emping jagung pulut 


\section{PENDAHULUAN}

\section{Latar Belakang}

Jagung merupakan tanaman pangan bijibijian yang memegang peranan penting setelah padi di Indonesia. Jumlah produksinya pada tahun 2010 adalah 18.327.636 ton atau kedua terbesar setelah padi yaitu 66.469.394 ton (Biro Pusat Statistik, 2010). Pada saat ini tanaman jagung dan kedelai mendapat prioritas utama untuk ditingkatkan produksinya. Peningkatan produksi tersebut juga diikuti dengan peningkatan pasca panen.

Sejalan dengan pesatnya peningkatan produksi jagung tersebut, sudah selayaknya dimanfaatkan untuk bahan baku industri yang strategis. Selain untuk pengadaan pangan dan pakan, jagung juga banyak digunakan dalam industri makanan, minuman, kimia, dan farmasi. Emping adalah salah satu produk olahan pangan dari bahan berpati yang dipipihkan menjadi lempengan dengan bentuk tertentu (biasanya bulat), dikeringkan, dan digoreng. Persoalan yang paling sering terjadi pada emping jagung adalah dalam hal penyimpanannya. Salah satu cara untuk mencegah hal tersebut adalah mengurangi kadar air bahan sehingga tekanan uap air bahan pada suhu tertentu seimbang dengan tekanan uap air lingkungannya. Pengetahuan tentang kadar air kesetimbangan ini diperlukan dalam perhitungan-perhitungan desain sistem pengeringan maupun penyimpanan bahan.

\section{Tujuan Penelitian}

Tujuan penelitian adalah untuk menguji persamaan sorpsi isotermi emping jagung yang memberikan perkiraan kadar air keseimbangan yang paling mendekati kadar air keseimbangan terukur. Selain itu, Penelitian ini juga bertujuan untuk mengetahui kerapuhan (daya patah) emping jagung pulut pada berbagai beberapa kondisi penyimpanan.

Kegunaan penelitian ini adalah diharapkan persamaan dan grafik isotermi yang diperoleh akan menambah informasi tentang kadar air keseimbangan emping jagung pulut selama penyimpanan dan selanjutnya persamaan ini digunakan untuk perhitungan-perhitungan yang menggunakan kadar air emping jagung ketika mendesain sistem penyimpanan. Selain itu data nilai daya patah sebagai bahan informasi masyarakat dalam mengolah emping jagung.

\section{METODOLOGI PENELITIAN}

\begin{abstract}
Alat
Adapun alat-alat yang digunakan adalah climatic chumber, texture analyzer, timbangan digital dan oven.
\end{abstract}

\section{Bahan}

Bahan yang digunakan adalah emping jagung pulut sebanyak 27 keping, dengan masing-masing perlakuan 3 kali ulangan. Adapun RH yang digunakan adalah $40 \%$, $60 \%$ dan $80 \%$, sedangkan suhu yang digunakan adalah $25^{\circ} \mathrm{C}, 30^{\circ} \mathrm{C}$ dan $35^{\circ} \mathrm{C}$ dengan perlakuan sebanyak 9 kali.

\section{Prosedur Penelitian}

Prosedur penelitian meliputi pengadaan sampel, penimbangan sampel, pengujian sampel, pengujian daya patah, penentuan kadar air sampel, penentuan sorpsi isotermi, dan pengujian ketepatan model.

\section{Pengadaan sampel}

Sampel emping dibuat dengan ketebalan $\pm 1 \mathrm{~mm}$ dan diameter $10 \mathrm{~cm}$. Dibuat dengan standarisasi yang sama, yaitu dengan berat jagung $75 \mathrm{~g}$ dilebarkan dalam luasan plastik $399,5 \mathrm{~cm} 2$, menghasilkan emping jagung 12 keping.

\section{Penimbangan sampel}

Sampel emping kemudian ditimbang terlebih dahulu sebelum dilakukan pengujian.

\section{Pengujian sampel}

Sampel kemudian dimasukkan kedalam climatic chumber dengan menyetel suhu dan RH sesuai dengan perlakuan, suhu yang dipakai, Penimbangan sampel dilakukan setiap 24 jam sampai mencapai berat konstan atau perubahan terjadi $( \pm 0,005 \mathrm{~g})$. Perlakuan selanjutnya sama namun terlebih dahulu menyetel suhu dan kelembaban sesuai perlakuan.

\section{Pengujian daya patah}

Setelah berat konstan dicapai, sampel dikeluarkan dari climatic chumber untuk uji daya patah dengan menggunakan texture analyzer. 


\section{Penentuan kadar air sampel}

Emping jagung yang telah di uji daya patahnya dihancurkan dengan cara diremas untuk menyeragamkan serta mempercepat proses pindah panas selama emping itu dikeringkan dalam oven. Setelah itu diambil sampel 10 gram dan dimasukkan dalam oven dengan suhu $115^{\circ} \mathrm{C}$ sampai berat konstan. Kadar air dinyatakan dalam basis kering (\%bk)

\section{Penentuan sorpsi isotermi}

Model persamaan sorpsi isotermi yang digunakan dalam penelitian ini adalah Henderson dan Chung dan Pfost. Pemilihan model persamaan ini didasarkan pada hasil penelitian sebelumnya bahwa kedua model tersebut cocok digunakan untuk kelembaban relatif (RH) 10\% - 90\%. Dengan demikian dapat mewakili keempat perlakuan.

1. Persamaan Henderson

$$
1-a_{w}=\operatorname{Exp}\left(-k \cdot T \cdot M e^{n}\right.
$$

\section{Persamaan Chung \& Pfost}

$$
\ln (R H)=\frac{-c_{1}}{R T} \operatorname{Exp}\left(-c_{2} \cdot M e\right)
$$

Untuk mendapatkan nilai $c_{1}$ dan $c_{2}$, digunakan metode kuadrat terkecil (least square) dengan cara, nilai Me untuk pasangan $\mathrm{RH}$ dan $\mathrm{T}$ masing-masing diregresi untuk mendapatkan nilai $c_{1}$ dan $c_{2}$ tersebut.

\section{Pengujian ketepatan model}

$$
P=\frac{100}{n} \sum \frac{\left|M_{i}-M p i\right|}{M_{i}}
$$

$\mathrm{P} \quad=$ Modulus deviasi

Mi = KA kesetimbangan hasil percobaan

Mpi = KA kesetimbangan hasil perhitungan

$\mathrm{n}=$ Jumlah data

\section{HASIL DAN PEMBAHASAN}

\section{Kadar Air Keseimbangan}

Hasil perhitungan kadar air awal sampel yaitu pada suhu $25^{\circ} \mathrm{C}$ dengan $\mathrm{RH} 40 \%, 60 \%$ dan $80 \%$ yaitu masing-masing $14,014 \%$ bk; $13,534 \%$ bk dan $14,954 \%$ bk. Pada suhu $30^{\circ} \mathrm{C}$ dengan RH 40\%, 60\% dan $80 \%$ yaitu masingmasing $16,787 \%$ bk; $12,215 \%$ bk dan $12,963 \%$ bk. Pada Suhu 35oC dengan RH
$40 \%$, 60\% dan $80 \%$ yaitu masing-masing $14,543 \%$ bk; $12,652 \%$ bk dan $16,499 \%$ bk. Bahan dengan kadar air tersebut kemudian digunakan sebagai sampel dalam penelitian ini.

Kondisi lingkungan tempat penyimpanan bahan (climatic chumber) sangat berpengaruh terhadap penentuan kadar air keseimbangan. Hal ini dapat dilihat pada hasil perhitungan setelah bahan disimpan pada kondisi lingkungan dengan berbagai kelembaban relatif (RH) dengan suhu relatif konstan sampai mencapai keadaan setimbang (terjadi perubahan berat yang relatif kecil). Perubahan kadar air itu dapat dilihat dari tabel berikut ini:

\begin{tabular}{|c|c|c|c|}
\hline \multicolumn{2}{|c|}{ Perlakuan } & \multirow{2}{*}{$\begin{array}{c}\text { Kadar Air } \\
\text { Awal } \\
(\% \text { bk })\end{array}$} & \multirow{2}{*}{$\begin{array}{c}\text { Kadar Air } \\
\text { Setimbang } \\
\quad(\% \text { bk })\end{array}$} \\
\hline Suhu & RH & & \\
\hline \multirow[t]{3}{*}{$25^{\circ} \mathrm{C}$} & $40 \%$ & 14,014 & 11,403 \\
\hline & $60 \%$ & 13,534 & 11,450 \\
\hline & $80 \%$ & 14,954 & 11,788 \\
\hline \multirow[t]{3}{*}{$30^{\circ} \mathrm{C}$} & $40 \%$ & 16,787 & 11,434 \\
\hline & $60 \%$ & 12,215 & 11,617 \\
\hline & $80 \%$ & 12,963 & 11,676 \\
\hline \multirow[t]{3}{*}{$35^{\circ} \mathrm{C}$} & $40 \%$ & 14,543 & 12,018 \\
\hline & $60 \%$ & 12,652 & 12,051 \\
\hline & $80 \%$ & 16,499 & 12,266 \\
\hline
\end{tabular}

Tabel 1. Perubahan kadar air bahan hingga menjadi setimbang

Menurut Henderson dan Perry (1967), jika aktivitas air bahan lebih tinggi dari kelembaban relatif lingkungan maka bahan akan melepaskan air dan jika kelembaban relatif lingkungan lebih tinggi dari aktivitas air maka bahan akan menyerap air. Hal ini sesuai dengan Tabel 1 dimana proses pelepasan air dari bahan ke lingkungan terjadi pada semua kondisi penyimpanan, terlihat bahwa kadar air awal lebih besar dari kadar air setimbang.

Pada Gambar 1 dapat dilihat kurva kecenderungan desorpsi isotermis. Secara umum terlihat bahwa pada saat-saat awal kadar air turun secara cepat dan kemudian perlahan-lahan menuju kadar air keseimbangannya. 


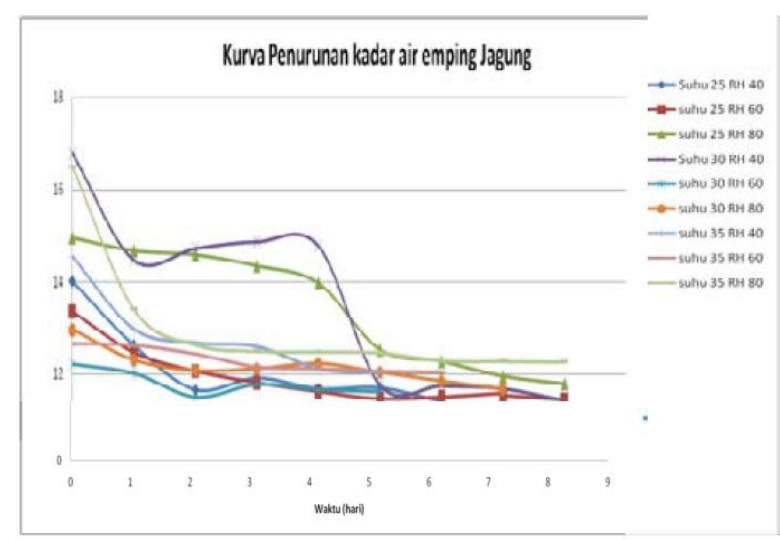

Gambar 2. Kurva penurunan kadar air emping jagung menuju keadaan setimbang

Pada suhu yang sama, kenaikan nilai Kelembaban relatif (RH) menyebabkan waktu untuk mencapai kadar air kesetimbangan semakin lama dan nilai kadar air keseimbangannya semakin tinggi. Pada RH yang sama, kenaikan nilai suhu akan mempercepat waktu untuk mencapai kesetimbangan dan nilai kadar air kesetimbangan semakin tinggi pula.

Menurut Porter et.al (1974), menyatakan bahwa proses desorpsi adalah proses keluarnya air atau uap air secara difusi. Pada peristiwa ini, terjadi dua proses secara simultan yaitu pindah panas dan energi untuk penguapan. Pindah massa yang berlangsung didalam bahan dapat berupa uanp air atau cairan. Air atau uap air akan bergerak menuju ke permukaan dan keluar dalam bentuk uap, hal ini terjadi karena adanya perbedaan konsentrat.

Dengan meningkatnya kelembaban relatif, kadar air keseimbangan emping jagung pulut semakin meningkat. Kelembab an relatif yang tinggi memiliki kemampuan menampung uap air yang tinggi sampai dapat kejenuhannya, sehingga uap air lebih banyak jika dibandingkan dengan bahan yang berada pada kelembaban rendah.

Proses penyerapan uap air terjadi karena tekanan uap air lingkungan lebih tinggi dari tekanan uap air bahan. Menurut Hall (1980), aliran atau migrasi air dari tempat bertekanan uap tinggi ke tempat bertekanan rendah adalah sebanding dengan selisih tekanan uap antara lingkungan dan bahan, maka proses perpindahan uap air akan terhenti dan kondisi setimbang akan tercapai.

\section{Sorpsi Isotermi}

Proses sorpsi isotermi yang terjadi pada penelitian ini hanya desorpsi yaitu pelepasan air dari bahan ke lingkungan untuk semua perlakuan RH (40\%, 60\% dan $80 \%)$ dan suhu $\left(25^{\circ} \mathrm{C}, 30^{\circ} \mathrm{C}\right.$ dan $\left.35^{\circ} \mathrm{C}\right)$. Semua perlakuan tersebut mengalami penurunan kadar air, seperti yang terlihat pada Tabel 1 diatas.

\section{Model Persamaan Sorpsi Isotermi}

Model yang dipakai pada penelitian ini yaitu Persamaan Henderson dan Persamaan Chung \& Pfost.

Secara empiris, Henderson mengemukakan persamaan yang menggambarkan hubungan antara kadar air kesetimbangan bahan pangan dengan kelembaban relatif ruang simpan. Persamaan Henderson berlaku untuk bahan pangan pada semua aktivitas air dan merupakan salah satu persamaan yang paling banyak digunakan pada bahan pangan kering. Sedangkan Persamaan Chung \& Pfost digunakan karena persamaan ini cocok untuk RH $10-90 \%$. Nilai konstanta setiap persamaan dapat dilihat pada tabel sebagai berikut:

Tabel 2. Nilai konstanta model persamaan emping jagung pulut.

\begin{tabular}{|c|c|c|c|}
\hline Perlakuan & \multirow{2}{*}{ Model } & \multicolumn{2}{|c|}{ Konstanta } \\
\hline Suhu & & $c_{1}$ & $c_{2}$ \\
\hline \multirow[t]{2}{*}{$25^{\circ} \mathrm{C}$} & $\begin{array}{l}\text { Persamaan } \\
\text { Henderson }\end{array}$ & $2,796 \mathrm{E}-34$ & 28,97379 \\
\hline & $\begin{array}{l}\text { Persamaan } \\
\text { Chung \& } \\
\text { PFost }\end{array}$ & $1,620 \mathrm{E}+22$ & 3,218958 \\
\hline \multirow[t]{2}{*}{$30^{\circ} \mathrm{C}$} & $\begin{array}{l}\text { Persamaan } \\
\text { Henderson }\end{array}$ & $4,482 \mathrm{E}-57$ & 50,36999 \\
\hline & $\begin{array}{l}\text { Persamaan } \\
\text { Chung \& } \\
\text { PFost }\end{array}$ & $3,394 \mathrm{E}+28$ & 5,195626 \\
\hline \multirow[t]{2}{*}{$35^{\circ} \mathrm{C}$} & $\begin{array}{l}\text { Persamaan } \\
\text { Henderson }\end{array}$ & $5,988 \mathrm{E}-55$ & 47,48608 \\
\hline & $\begin{array}{l}\text { Persamaan } \\
\text { Chung \& } \\
\text { PFost }\end{array}$ & $5,532 \mathrm{E}+23$ & 4,030243 \\
\hline
\end{tabular}

konstanta tersebut pada model persamaan, maka diperoleh Persamaan sorpsi isotermi emping jagung pulut Henderson sebagai berikut :

$$
M e_{\text {Henderson }}=\left(\frac{\ln \left(1-a_{w}\right)}{-1,592 \times 10^{-31}}\right)^{\frac{1}{28,97379}}
$$




$$
\begin{aligned}
M e_{\text {Henderson }} & =\left(\frac{\ln \left(1-a_{w)}\right.}{-1,592 \times 10^{-31}}\right)^{\frac{1}{50,36999}} \\
M e_{\text {Henderson }} & =\left(\frac{\ln \left(1-a_{w)}\right.}{-1,592 \times 10^{-31}}\right)^{\frac{1}{47,48608}}
\end{aligned}
$$

Dengan COD (coefficcient of determination) pada suhu $250 \mathrm{C}$ sebesar $99,74 \%$, suhu $30^{\circ} \mathrm{C}$ sebesar $96,03 \%$ dan suhu $35^{\circ} \mathrm{C}$ sebesar $99,99 \%$. Ketiga persamaan diatas disatukan dengan cara meregresi semua nilai Me pada setiap pasangan suhu dan $a_{w}$ didapatkan Persamaan Umum Sorpsi Isotermi Emping Jagung Pulut Henderson dengan COD 97\%, sebagai berikut:

$$
M e_{\text {Henderson }}=\left(\frac{\ln \left(1-a_{w)}\right.}{6,19648 \times 10^{-19} T}\right)^{\frac{1}{28,97379}}
$$

Persamaan kadar air keseimbangan yang didasarkan pada persamaan Chung \& Pfost. Regresi Nilai Me dengan metode kuadrat terkecil menghasilkan persamaan kadar air kesetimbangan berikut berturut-turut untuk suhu $25^{\circ} \mathrm{C}, 30^{\circ} \mathrm{C}$ dan $35^{\circ} \mathrm{C}$ :

$$
\begin{aligned}
& M e=-\frac{1}{3,21895799} \ln \left(\frac{1,62091 \times 10^{22}}{-(298,15 R) \ln a_{w}}\right) \\
& M e=-\frac{1}{5,19562584} \ln \left(\frac{1,56729 \times 10^{32}}{-(303,15 R) \ln a_{w}}\right) \\
& M e=-\frac{1}{4,03024227} \ln \left(\frac{3,07427 \times 10^{23}}{-(308,15 R) \ln a_{w}}\right)
\end{aligned}
$$

dengan COD (coefficcient of determination) setiap suhu sama, sebesar 99,01\%. Dengan metode yang sama dengan persamaan Henderson, ketiga persamaan tersebut diregresi semua nilai Me pada setiap pasangan suhu dan $a_{w}$ didapatkan persamaan umum sebagai berikut :

$$
M e_{\text {Chung \& Pfost }}=-\frac{1}{29,93184142} \ln \left(\frac{5,4828 \times 10^{99}}{-(R T) \ln a_{w}}\right)
$$

dengan COD sebesar 69\%, maka Model Persamaan Henderson lebih tepat untuk mewakili data yang diregresi dibandingkan Persamaan Chung \& Pfost.

Koefisien determinasi atau COD (coefficcient of determination) mencerminkan seberapa besar kemampuan variabel bebas dalam menjelaskan varians variabel terikatnya. Koefisien ini mempunyai nilai antara $0-1$ atau dinyatakan dalam persen $(\%)$ di mana nilai yang mendekati 1 berarti semakin tinggi kemampuan variabel bebas dalam menjelaskan varians variabel terikatnya.

\section{Kurva Sorpsi Isotermi}

Kurva sorpsi isotermi adalah kurva yang menggambarkan hubungan antara kandungan air dalam bahan pangan dengan aktivitas air atau kelembaban relatif ruang penyimpanan. Kurva sorpsi isotermi untuk Persamaan Henderson dapat dilihat pada Gambar 3.

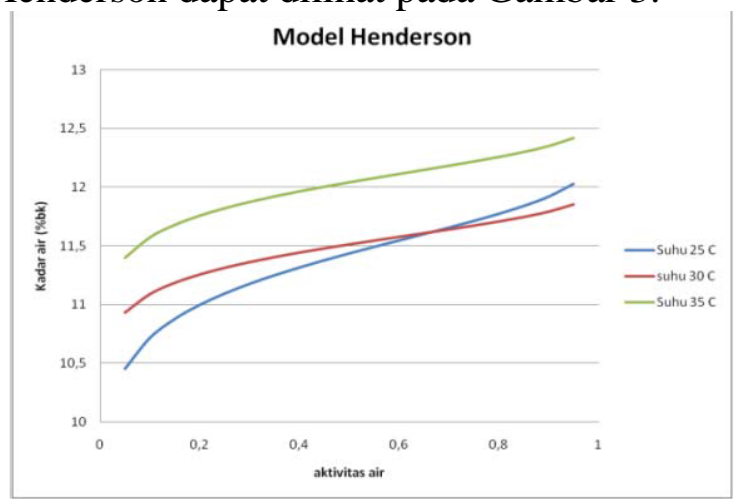

Gambar 3. Kurva kadar air keseimbangan dari model persamaan Henderson

Menurut Brooker et.al. (1981), kurva sorpsi isotermis terbentuk dari suatu produk pangan dapat digunakan untuk menentukan umur simpannya. Pada penelitian ini, kurva sorpsi isotermi dibuat dengan cara memplot nilai kadar air kesetimbangan Persamaan Henderson dengan kelembaban relatif dari nilai $0,5-0,95$ dengan interval 0,5 pada suhu $25^{\circ} \mathrm{C}, \quad 30^{\circ} \mathrm{C}$ dan $35^{\circ} \mathrm{C}$. Sedangkan pada Persamaan Chung \& Pfost dapat dilihat pada Gambar 4 dibawah ini. 


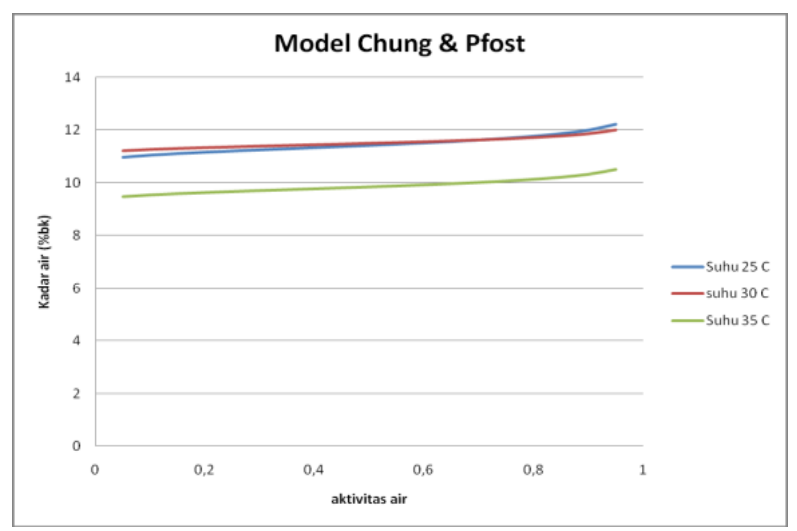

Gambar 4. Kurva kadar air kesetimbangan dari model persamaan Chung \& Pfost.

Labuza dan Bilge dalam Brooker, et.al. (1981), menyatakan bahwa aktivitas air dapat dihitung dengan membagi ERH lingkungan dengan nilai 100, karena pada keadaan equilibrium atau setimbang aktivitas air bahan akan sama dengan kelembaban nisbi udara sekelilingnya. Gambar 3 dan 4 menunjukkan bahwa kurva sorpsi isotermi kedua persamaan berbentuk sigmoid, yaitu menyerupai huruf $S$ walaupun tidak sigmoid sempurna. Namun kedua kurva tersebut berbeda dan khas untuk masing-masing persamaan.

Menurut SNI 01 - 2001, kadar air maksimum untuk emping adalah $12 \%$ bk. Aktivitas air bahan berkaitan erat dengan kadar air, yang umumnya dapat menggambarkan pertumbuhan bakteri, jamur dan mikroba lainnya. Pada umumnya semakin tinggi aktivitas air, maka semakin banyak bakteri yang tumbuh, sedangkan jamur sebaliknya tidak menyukai aktvitas air yang terlalu tinggi. Adapun hubungan aktivitas air dan kondisi bahan pangan dapat dilihat pada Tabel berikut.

Tabel 3. Hubungan aktivitas air dan kondisi bahan pangan

\begin{tabular}{ccl}
\hline No & $\begin{array}{c}\text { Nilai } \\
\text { Aktivitas } \\
\text { Air }\end{array}$ & \multicolumn{1}{c}{ Kondisi Bahan Pangan } \\
\hline 1 & $>0,75$ & $\begin{array}{l}\text { Bahan pangan mulai tidak aman } \\
\text { untuk dikonsumsi } \\
\text { Mikroorganisme berbahaya } \\
\text { mulai tumbuh dan produk } \\
\text { menjadi beracun }\end{array}$ \\
3 & $0,7-0,75$ & $\begin{array}{l}\text { Jamur mulai tumbuh } \\
\text { Makanan ringan hilang } \\
\text { kerenyahan }\end{array}$ \\
4 & $0,6-0,0,0,5$ & $\begin{array}{l}\text { Produk pasta yang terlalu kering } \\
\text { akan mudah hancur dan rapuh }\end{array}$ \\
\hline
\end{tabular}

\section{Uji Ketepatan Model}

Uji ketepatan model Henderson dan Chung \& Pfost menggunakan data kadar air ke-setimbangan hasil perhitungan model. Nilai kadar air kesetimbangan dapat dilihat pada Tabel 4.

Tabel 4. Kadar air kesetimbangan emping jagung pulut (\% bk) percobaan dan hasil perhitungan dengan menggunakan model Henderson dan Chung \& Pfost

\begin{tabular}{|c|c|c|c|c|}
\hline \multicolumn{2}{|c|}{ Perlakuan } & \multirow[b]{2}{*}{ Observasi } & \multicolumn{2}{|c|}{ Model } \\
\hline Suhu & $a_{w}$ & & $\begin{array}{c}\text { Chung \& } \\
\text { Pfost }\end{array}$ & Henderson \\
\hline \multirow[t]{3}{*}{$25^{\circ} \mathrm{C}$} & 0,4 & 11,403085 & 11,340459 & 11,318198 \\
\hline & 0,6 & 11,434266 & 11,521979 & 11,443616 \\
\hline & 0,8 & 11,450549 & 11,779272 & 11,548765 \\
\hline \multirow[t]{3}{*}{$30^{\circ} \mathrm{C}$} & 0,4 & 11,617943 & 11,447915 & 11,577138 \\
\hline & 0,6 & 11,676451 & 11,560376 & 11,711202 \\
\hline & 0,8 & 11,788079 & 11,719782 & 11,775493 \\
\hline \multirow[t]{3}{*}{$35^{\circ} \mathrm{C}$} & 0,4 & 12,018925 & 9,7795985 & 11,965605 \\
\hline & 0,6 & 12,163905 & 9,9245770 & 12,113749 \\
\hline & 0,8 & 12,369405 & 10,130076 & 12,258304 \\
\hline
\end{tabular}

Pengujian untuk setiap model persamaan sorpsi isotermi dilakukan dengan uji ketepatan model menggunakan kriteria modulus deviasi $(\mathrm{P})$ seperti pada (Persamaan 7). Nilai Uji ketepatan Model emping jagung pulut dapat dilihat pada Tabel 5.

\begin{tabular}{|c|c|c|c|}
\hline \multicolumn{2}{|c|}{ Perlakuan } & \multicolumn{2}{|c|}{ Modulus Deviasi } \\
\hline Suhu & $R H$ & Henderson & Chung \& Pfost \\
\hline \multirow[t]{3}{*}{$25^{\circ} \mathrm{C}$} & $40 \%$ & & \\
\hline & $60 \%$ & $0,569 *$ & $0,415 *$ \\
\hline & $80 \%$ & & \\
\hline \multirow[t]{3}{*}{$30^{\circ} \mathrm{C}$} & $40 \%$ & & \\
\hline & $60 \%$ & $0,243^{*}$ & $\mathbf{0 , 3 2 5 *}$ \\
\hline & $80 \%$ & & \\
\hline \multirow[t]{3}{*}{$35^{\circ} \mathrm{C}$} & $40 \%$ & & \\
\hline & $60 \%$ & $0,342 *$ & 21,81 \\
\hline & $80 \%$ & & \\
\hline
\end{tabular}

Jika nilai uji modulus deviasi (P) mendekati nol maka model tersebut dapat menggambar-kan secara tepat keadaan sorpsi isotermi yang sebenarnya. Nilai uji modulus deviasi diatas 10 tidak dianggap menggambarkan keadaan yang sebenarnya.

Pada Tabel 5 terlihat bahwa Nilai uji modulus deviasi (P) mendekati nol, kecuali pada perlakuan suhu 35oC pada model Chung \& Pfost, sehingga disimpulkan bahwa Persamaan Henderson lebih tepat dalam menggambarkan kondisi sorpsi isotermi emping jagung pulut. 


\section{Daya Patah}

Nilai daya patah emping jagung pulut diukur setelah emping jagung pulut setimbang kadar airnya. Sampel di uji dengan menggunakan texture analyzer. Dengan pengujian menggunakan alat tersebut, data yang didapat berupa force $(\mathrm{N})$, distance $(\mathrm{mm})$ dan Time (sec). Untuk mendapatkan nilai daya patah, menggunakan persamaan :

$W=\operatorname{Kerja}(\mathrm{J})$

$$
\begin{gathered}
W=F . s \\
P=\frac{w}{t}
\end{gathered}
$$

$P=$ Daya $(\mathrm{J} / \mathrm{det})$

Hasil Penelitian menunjukkan bahwa nilai daya patah emping jagung cenderung menurun dengan semakin meningkatnya Kelembaban relatif (RH) lingkungan. Hasil pengukuran Nilai daya patah emping jagung pulut dapat dilihat pada Tabel 6 .

Tabel 6. Hasil pengukuran Nilai daya patah emping jagung pulut pada kondisi setimbang.

\begin{tabular}{cc}
\hline $\begin{array}{c}\text { Kadar Air Setimbang } \\
(\% \text { bk })\end{array}$ & $\begin{array}{c}\text { Daya Patah } \\
(\mathrm{J} / \text { det })\end{array}$ \\
\hline 11,403 & 0,0015 \\
11,451 & 0,0008 \\
11,788 & 0,0016 \\
11,434 & 0,0029 \\
11,618 & 0,0018 \\
\hline 11,676 & 0,0019 \\
12,019 & 0,0033 \\
12,052 & 0,0033 \\
12,267 & 0,0028 \\
\hline
\end{tabular}

Hasil Penelitian menunjukkan bahwa semakin rendah kadar airnya maka nilai daya patahnya semakin rendah, hal ini disebabkan karena emping semakin kokoh dan kuat, sehingga membutuhkan gaya yang cukup besar untuk bisa mematahkan-nya, dibandingkan dengan emping yang memiliki kadar air tinggi, daya patahnya tinggi, karena tekstur emping yang lunak sehingga mudah patah.

\section{KESIMPULAN}

Berdasarkan penelitian yang telah dilaksanakan, maka dapat ditarik kesimpulan sebagai berikut:

1. Dari kedua persamaan yang diuji yaitu Persamaan Henderson dan Persamaan Chung \& Pfost, Persamaan Henderson memberikan perkiraan perilaku sorpsi isotermi emping jagung pulut lebih mendekati hasil pengukuran pada kondisi suhu $30^{\circ} \mathrm{C}$ dan $35^{\circ} \mathrm{C}$, sedangkan Persamaan Chung \& Pfost paling baik menggambarkan perilaku sorpsi isotermi pada suhu $25^{\circ} \mathrm{C}$.

2. Nilai daya patah berbanding lurus dengan RH lingkungan. Semakin tinggi RH lingkungan maka Nilai daya patah juga semakin tinggi.

\section{DAFTAR PUSTAKA}

Andrade, R. D., Lemus, R., dan Perez, C. (2011). Models of Sorpsi Isotherms for food: Uses and Limitations. The Revista De La Facultad De Quimica Farmaceutica Universidad de Antioquia Medellin, Columbia Vol. 18 No. 2. 2011, pages 325-334.

Anna, C. E., Bustami dan Ibrahim. (2011). Pendugaan Umum Simpan Produk Cone Es Krim dengan Metode AkselerasiModel Kadar Air Kritis. Institut Pertanian Bogor

Anonim, .(2011). Jagung. http://id.wikipedia.org/wiki/Jagung. Tanggal akses 28 Januari 2011.

Azrai, M., Mejaya, M. J., Yasin, H.G.M,. 2011. Pemuliaan jagung khusus. http://balitsereal. litbang.deptan.go. id/ind/bjagung/tujuh.pdf. Tanggal Akses 21 Maret 2011

Brokeer, D. B., Bakker, F. W., dan Hall, C. W.(1981). Drying Cereal Grains. The AVIPub.Co.Inc. Westport: Connecticut. 
Haryati, S. (1997). Mempelajari Sorpsi Isotermi dan Kerapuhan Mie Kering Instan yang Disimpan pada Berbagai Kondisi Penyimpanan. Institut Pertanian Bogor.

Jumadi, (2008). Pengkajian Teknologi Tortila Jagung. Buletin Teknik Pertanian Vol. 13 No. 2. Hal 73-74

Manalu, L.P. 2001. Model Persamaan kadar air Keseimbangan Desorpsi Isotermis Jagung. Buletin Teknik Pertanian Vol. 15 No. 1. Hal 17-25

Nur Richana dan Suarni. (2003). Jagung: Teknik Produksi dan Pengembangan. Balai Besar Penelitian \& Pengembangan Pascapanen, Bogor dan Balai Penelitian Tanaman Serealia, Maros.

Reo, A. R. 2010. Efek Suhu Terhadap Moisture Sorpsion Isotherm dari Ikan Kerapu (Epinrphelus merra) Asin Kering dan Ikan Cakalang (Katsuwonus pelamis L) Asap. Jurnal Teknologi Pertanian Vol. 5 No. 2 Hal. 41 - 47. 